\title{
Effect of Liming and Fertilization on Productivity and Species Balance of a Tropical Kudzu- Molassesgrass Pasture Under Grazing Management ${ }^{1}$
}

\author{
Rubén Caro-Costas and José Vicente-Chandler ${ }^{2}$
}

\section{INTRODUCTION}

Tropical kudzu (Pucraria phaseoloides) and molassesgrass (Melinis minutiflora) mixtures make excellent pastures for the Humid Mountain Region of Puerto Rico. In experiments by Vicente-Chandler, et al. (4) ${ }^{3}$, steep kudzu-molassesgrass pastures receiving little care or fertilization, carried 1 head and produced almost 500 pounds of gain in weight per acre yearly for 10 consecutive years under typical conditions in the Mountain Region.

There is little information on the fertility requirements of tropical kudzumolassesgrass mixtures, particularly under grazing management to which both these forages are best suited. Vicente-Chandler and Caro-Costas ( 3 ) found that a kudzu-molassesgrass mixture growing on Múcara clay and harvested by cutting did not respond to fertilization with phosphorus or potassium. Abruña and Figarella (1) found that yield and protein content of tropical kudzu, growing in association with molassesgrass on a Catalina clay, and harvested by cutting, were increased by liming, but that yield and composition of the grass were not affected. Phosphorus applications did not affect yields, but increased the phosphorus content of the grass.

This paper presents results of a study of the effects of lime, phosphorus, potassium, and nitrogen applications on the productivity, species balance, and chemical composition of a tropical kudzu-molassesgrass mixture with actual grazing management under conditions typical of the Humid Mountain Region of Puerto Rico.

\section{MATERIALS AND METHODS}

The experiment was carried out over a 3-year period at Orocovis. Mean annual temperature was about $75^{\circ} \mathrm{F}$., with seasonal variations of about $10^{\circ} \mathrm{F}$. Highest daily temperatures rarely exceeded $85^{\circ} \mathrm{F}$. or fell below $65^{\circ} \mathrm{F}$.

1 This paper covers work carried out cooperatively between the Soil and Water Conservation Research Division, Agricultural Research Service, USDA, and the Agricultural Experiment Station, University of Puerto Rico, Río Piedras, P.R.

${ }^{2}$ Agronomist, cooperative between USDA and the Puerto Rico Station, and Project Supervisor, Soil and Water Conservation Research Division, Agricultural Research Service, USDA, respectively.

Italic numbers in parentheses refer to Litcrature Cited p. 241. 
Annual rainfall averaged 61.1 inches and was fairly well distributed, with lowest precipitation from December through March.

The soil is Catalina clay, a deep, red latosol, with predominantly kaolinitic clay minerals and a high free iron oxide content. Other characteristics of the upper 6 inches of this soil are shown below:

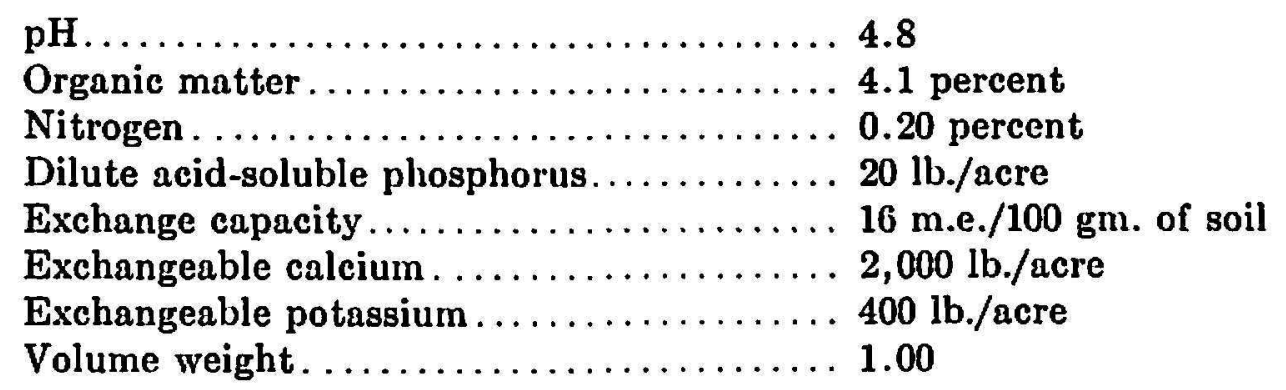

Treatments tested are shown in table 1. Limestone and phosphorus (as 20-percent superphosphate) were applied in one surface application at the start of the experiment. Nitrogen, as ammonium sulfate, and potassium as potassium chloride, were applied in four equal applications yearly. A randomized block design was used with all treatments, replicated six times in a field of tropical kudzu-molassesgrass. Plots were $10 \times 20$ feet in size, surrounded by ditches to prevent fertilizer from washing into adjoining plots.

The forage in all plots was grazed down to a height of approximately 8 inches about every 40 days. The relative effects of the treatments at the end of 3 years were determined by harvesting the forage produced in

TABLE 1.-Effect of liming and fertilization over 3 successive years, with
grazing management, on yield and species composition of a tropical
h:udzu-molassesgrass mixlure over a final $\$$-month period

\begin{tabular}{|c|c|c|c|c|c|c|c|c|}
\hline \multirow{2}{*}{$\begin{array}{l}\text { Treatment } \\
\text { No. }\end{array}$} & \multicolumn{4}{|c|}{$\begin{array}{l}\text { Fertility trentment applied } \\
\text { per acre }\end{array}$} & \multirow{2}{*}{$\begin{array}{l}\text { Yields of } \\
\text { dry forage } \\
\text { produced } \\
\text { per acre }\end{array}$} & \multicolumn{3}{|c|}{$\begin{array}{l}\text { Species composition of forage } \\
\text { on a dry-weight basis }\end{array}$} \\
\hline & $\begin{array}{l}\text { Limestone } \\
\text { (initially) }\end{array}$ & $\underset{\text { (initially) }}{\mathrm{P}_{2} \mathrm{O}_{5}}$ & $\underset{\text { (yearly) }}{\mathbf{K}}$ & $\underset{\text { (yearly) }}{\mathbf{N}}$ & & $\begin{array}{l}\text { Tropical } \\
\text { kudzu }\end{array}$ & $\underset{\text { grass }}{\text { Molasses- }}$ & $\begin{array}{l}\text { Para } \\
\text { grass }\end{array}$ \\
\hline & Tons & Pounds & Pounds & Pounds & Pounds & Percenst & Percent & Percent \\
\hline 1 & 0 & 0 & 0 & 0 & 2,810 & 8.2 & 91.4 & 0.4 \\
\hline 2 & 4 & 200 & 300 & 0 & 4,620 & 23.8 & 76.2 & 0 \\
\hline 3 & 0 & 200 & 300 & 0 & 3,550 & 5.1 & 92.8 & 2.1 \\
\hline 4 & 4 & 0 & 300 & 0 & 4,790 & 18.2 & 81.3 & 0.5 \\
\hline 5 & 4 & 200 & 0 & 0 & 3,950 & 18.8 & 70.1 & 11.1 \\
\hline 6 & 4 & 200 & 300 & 200 & 6,520 & 2.1 & 91.9 & 6.0 \\
\hline 7 & 4 & 200 & 300 & 300 & 7,220 & 2.1 & 63.6 & 34.3 \\
\hline \multirow[t]{2}{*}{8} & 4 & 200 & 0 & 200 & 4,770 & 1.9 & 93.6 & 4.5 \\
\hline & & & & L.S.D. ${ }_{01}^{06}$ & $\begin{array}{l}1,660 \\
2,220\end{array}$ & $\begin{array}{r}8.6 \\
11.5\end{array}$ & - & $\begin{array}{l}18.2 \\
24.3\end{array}$ \\
\hline
\end{tabular}


all plots over a final 90-day period of favorable weather. The forage was harvested by cutting, weighed, separated by species, and samples of each species were dried and analyzed for various constituents.

\section{RESULTS AND DISCUSSION}

Applications of lime, phosphorus, and potassium together increased yields of the tropical kudzu-molassesgrass mixture from 2,810 to 4,620 pounds per acre (treatment 1 vs. 2 in table 1). In addition, the proportion of tropical kudzu was increased from 8.2 to 23.8 percent of the mixture and yields from 230 to 1,100 pounds of dry kudzu per acre.

Applications of phosphorus did not affect either yields or species balance

TABLE 2.-Effect of liming on dry-weight composition of a tropical kudzumolassesgrass pasture 3 years after limestone was applied

\begin{tabular}{|c|c|c|c|c|}
\hline \multirow{2}{*}{$\begin{array}{l}\text { Limestone applied per } \\
\text { acre } \\
\text { (tons) }\end{array}$} & \multirow{2}{*}{ Species } & \multicolumn{3}{|c|}{ Composition of foragel } \\
\hline & & Protein & Calcium & Manganese \\
\hline 0 (treatment 3) & Kudzu & $\begin{array}{l}\text { Percent } \\
10.6 \backslash\end{array}$ & $\begin{array}{l}\text { Percent } \\
0.97 \searrow\end{array}$ & $\begin{array}{l}\text { P.p.m. } \\
490 \backslash\end{array}$ \\
\hline 4 (treatment 2) & do. & $14.4 /$ & $1.27 /$ & $180 /$ \\
\hline 0 (treatment 3) & Molassesgrass & 05.5 & 0.44 & $260 \backslash$ \\
\hline 4 (treatment 2) & do. & $05.8 /$ & $0.52 /$ & $120 /$ \\
\hline
\end{tabular}

1 * Statistically significant at ${ }^{05}$ level; ** statistically significant at ${ }^{01}$ level; NS Not significant statistically.

of the pastures (treatment 2 2's. 4), but significantly increased the content of phosphorus, an important factor in animal nutrition, in kudzu from 0.12 to 0.15 percent, and in molassesgrass from 0.11 to 0.17 percent.

Applications of potassium did not affect yields when no nitrogen was applied (treatment 5 vs. 2). However, with 200 pounds of nitrogen the application of 300 pounds of potassium increased yields from 4,770 to 6,520 pounds of dry forage per acre (treatment $8 v s .6$ ). Potassium fertlization did not affect the species balance in either case.

Liming increased the proportion of tropical kudzu from 5.1 to 23.8 percent of the mixture (treatment $3 \mathrm{vs.} 2$ in table 1) and yields from 181 to 1,100 pounds of dry kudzu per acre. Table 2 shows that liming increased the protein from 10.6 to 14.4 percent and calcium from 0.97 to 1.27 percent of the kudzu while decreasing the content of manganese from 490 to 180 p.p.m. Liming also increased the calcium and reduced the manganese content of molassesgrass (table 2). Liming may have favored the growth of 
tropical kudzu by increasing the supply of available calcium, as indicated by the higher calcium content of kudzu in the limed plots, or by furthering activity of nitrogen-fixing bacteria, as indicated by the higher protein content of kudzu in the limed plots, or more likely by reducing the uptake of manganese, which approached toxic levels in kudzu growing in the unlimed plots. In any case, the desirability of liming kudzu-molassesgrass pastures growing on Catalina clay or similar soils with a $\mathrm{pH}$ below about 5.0 is evident from these data.

The application of 200 pounds of nitrogen per acre yearly increased yields of dry forage from 4,620 to 6,520 pounds per acre, but resulted in the virtual elimination of tropical kudzu, which decreased from 23.8 to 2.1 percent of the mixture (treatment 2 vs. 6). Increasing nitrogen rates to 300 pounds per acre did not further increase forage yields, but resulted in a strong invasion of Para grass which increased from 6.0 to 34.3 percent of the mixture (treatment $6 \mathrm{vs}$. 7). These data show that the invasion of tropical kudzu-molassesgrass pastures by Para grass, reported by VicenteChandler, et al. (4), is a result of enhanced soil fertility which favors this higher-yielding grass. The data also confirm the findings of Caro and Vicente-Chandler (2) that molassesgrass does not respond to the application of more than about 200 pounds of nitrogen per acre yearly.

It is evident that yields of tropical kudzu-molassesgrass pastures cannot be increased much by nitrogen fertilization without erradicating the kudzu, although it may be possible occasionally to increase productivity of these pastures over critical periods by moderate applications of nitrogen without permanently affecting species balance. On the other hand, if the proportion of kudzu becomes too high, as often occurs, it may be possible to restore a desirable species balance by judicious fertilization with nitrogen.

\section{SUMMARY}

The effects of lime, phosphorus, potassium, and nitrogen applications on the productivity, species balance, and chemical composition of a tropical kudzu-molassesgrass mixture growing under grazing management on a latosol in the Humid Mountain Region of Puerto Rico were determined.

Yields of tropical kudzu and molassesgrass, and the proportion of kudzu in the mixture were increased by combined applications of lime, phosphorus, and potassium. Yields and species balance were not affected by applications of phosphorus or potassium individually when no nitrogen was applied. However, when nitrogen was applied, the pastures responded in yield to applications of potassium but species balance was not affected.

Liming increased both yields of kudzu and the proportion of this legume in the mixture about fivefold. Liming also increased the protein and 
calcium contents of tropical kudzu and sharply reduced the abnormally high manganese content of unlimed kudzu.

The application of 200 pounds of nitrogen per acre yearly increased forage yields, but resulted in the virtual disappearance of tropical kudzu from the mixture. Heavier applications of nitrogen did not further increase yields, but resulted in a marked invasion of the pastures by Para grass. It is apparent that yields of tropical kudzu-molassesgrass pastures cannot be increased much by nitrogen fertilization without erradicating the kudzu. However, if kudzu becomes dominant, as is often the case, it may be possible to restore a desirable species balance by judicious applications of nitrogen.

\section{RESUMEN}

Se estudió el efecto de las aplicaciones de cal, fósforo, potasio y nitrógeno sobre el rendimiento y proporción de ambas especies, y la composición química del forraje del kudzú tropical (Pueraria phaseoloides) y la yerba melao (melinis minutiflora) sembradas en asociación para pastoreo en un tipo de suelo latosol en la región húmeda y montañosa de Puerto Rico.

La aplicación combinada de cal, fósforo y potasio aumentó el rendimiento de los pastos así como la proporción de kudzú en la asociación. Las aplicaciones individuales de fosforo o potasio no afectaron ni el rendimiento ni la proporción de los pastos cuando no se aplicó nitrógeno. En cambio, cuando se aplicó nitrógeno, las aplicaciones de potasio aumentaron el rendimiento de los pastos sin que se afectara la proporción de kudzú en la asociación.

Las aplicaciones de cal aumentaron alrededor de cinco veces más la proporción de kudzú en los pastos y el rendimiento de esta leguminosa, aumentando también su contenido de calcio y proteínas y reduciendo considerablemente su contenido de manganeso que era anormalmente alto en las parcelas sin encalar.

La aplicación de 200 libras de nitrógeno por cuerda anualmente aumentó el rendimiento de forraje, pero resultó en la desaparición casi total del kudzú tropical. Cuando se aumentó aún más la cantidad de nitrógeno no aumentaron los rendimientos, pero se vieron invadidas las parcelas por la yerba Para (Panicum barbinode).

Los datos demuestran que no es posible aumentar mucho el rendimiento de los pastos de kudzú tropical y yerba melao mediante las aplicaciones de nitrógeno sin que desaparezca el kudzú de la asociación. Por otro lado, puede disminuirse la excesiva ascendencia del kudzú en la asociación, lo cual ocurre con frecuencia, y restaurarse una deseable proporción de las especies, mediante aplicaciones ocasionales de nitrógeno. 


\section{LITERATURE CITED}

1. Abruña, F., and Figarella, J., Some effects of calcium and phosphorus fertilization on the yield and composition of a tropical kudzu-grass pasture, J. Agr. Univ. P.R. 41 (4) 231-5, 1957.

2. Caro-Costas, R., Vicente-Chandler, J., and Figarella, J., The yield and composition of five grasses growing in the humid mountains of Puerto Rico, as affected by nitrogen fertilization, season, and harvest procedure, J. Agr. Univ. P.R. 44 (3) $107-20,1960$.

3. Vicente-Chandler, J., and Caro-Costas, R., The effect of two heights of cutting and three fertility levels on the yield, protein content and species composition of a tropical kudzu-molassesgrass pasture, Agron. J. 45 (9) 397-400, 1953.

4. Vicente-Chandler, J., Pearson, R. W., Caro-Costas, R., Abruña, F., Figarella, J., and Silva, S., The intensive management of the major forages of Puerto Rico, Bul., Agr. Exp. Sta., Univ. P.R.; in process of publication. 